\title{
Animeldelse:
}

\section{Efter Det Arabiske Forår}

Af Julie Mundeling Nielsen

I Efter Foråret gennemgår Rasmus Alenius Boserup en række af de faktorer, der gjorde, at Det Arabiske Forår udviklede sig fra en helt utrolig chance for at få mere retfærdige og demokratiske samfund i Mellemøsten til en situation, der virker endnu mere fastlåst og nedslående, end før oprørene begyndte. Boserup punkterer samtidig en række af de myter og forudindtagede meninger, der er opståt i forbindelse med Det Arabiske Forår, og han forsøger at give et bud på, hvor Mellemøsten er på vej hen nu, hvor Foråret er forbi.

Rasmus Alenius Boserup: Efter Foråret Forandringer i Arabisk Politik.

Gyldendal, 2016. 191 s.

Det Arabiske Forår siges som oftest at tage sin begyndelse i slutningen af 2010, da den tunesiske grøntsagssælger og akademiker Mohamed Bouazizi sætter ild på sig selv efter politiets beslaglæggelse af den vogn, som han sælger frugt og grønt fra. Umiddelbart efter begynder de første demonstrationer, der med deres krav om medbestemmelse og retten til et værdigt liv som dominobrikker vælter den ene

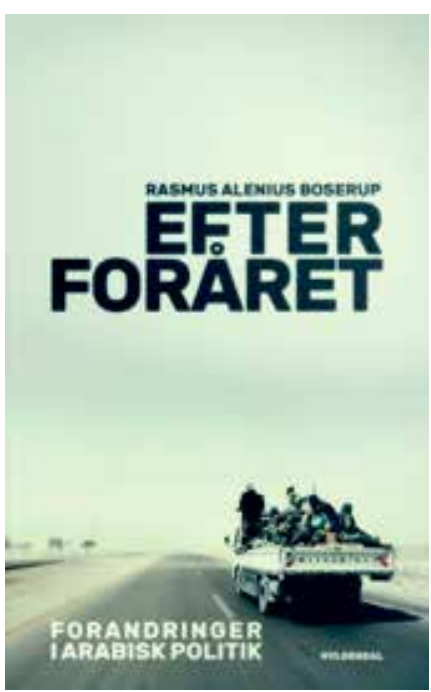

mellemøstlige diktator efter den anden. Det skulle dog hurtigt vise sig, at det ikke var så enkelt. Det Arabiske Forår, der fra starten virkede så lovende, viste sig nærmere at være et arabisk helvede, hvor situationen mest af alt blev værre. Mellemøsten, der til at starte med havde vist sig fra sin mest uforudsigelige side og overrasket næsten alle kendere af området, endte med at tage ét skridt frem og to

Julie Mundeling Nielsen er cand.mag. i Mellemøststudier og har skrevet speciale om borgerkrigen i Syrien. 
tilbage til endnu mere diktatoriske stater, ustabilitet og krig.

Men er det virkelig så simpelt? Spørger man forfatteren Rasmus Alenius Boserup, vil svaret helt sikkert være nej. Han har som seniorforsker ved DIIS og tidligere direktør for Dansk-Egyptisk dialoginstitut i Kairo noget at have sin holdning i, og han beskriver selv formålet med bogen som et forsøg på at gøre op med nogle af de mest almindelige fordomme om Det Arabiske Forårs årsag, forløb og efterspil på en måde, der måske kan ændre folks billede af ikke bare Det Arabiske Forår, men af regionen i sin helhed.

\section{Et spirende forår}

I bogen gennemgår Boserup Det Arabiske Forårs forskellige faser; fra revolutionens start, over kontrarevolutioner, militarisering, statskollaps, rivalisering og stormagtskamp for at ende ved en konklusion og vurdering af, hvordan Mellemøsten kan bevæge sig videre efter de enorme omvæltninger der er sket i forbindelse med oprørene. På baggrund af Boserups tidligere job og landets centrale placering $\mathrm{i}$ regionen både geografisk og politisk ligger fokus i bogen hovedsageligt på Egypten, men den kommer i løbet af de seks kapitler og konklusion ind på flere af de centrale lande og konflikter i Det Arabiske Forår og bruger dem som sammenligning og uddybning af de emner, som gennemgås.

En af de gennemgående pointer i bogen er, at der ikke er noget specifikt ved Mellemøsten eller dens befolkning, der gør, at de oprør, som opstod i forbindelse med Det Arabiske Forår, var dømt til at mislykkes, men at der var en række faktorer, der modarbejdede de ellers generelt positive forandringer.

Størstedelen af oprørene startede ud med at have medbestemmelse og antikor- ruption som hovedmål, og de så et langt stykke hen ad vejen ud til at ville lykkes. Boserup argumenterer herefter for, at det bl.a. var en kontrarevolutionær proces, der vendte om på op udviklingen. I Egypten var det eksempelvis den nyvalgte præsident Morsis forsøg på at give sig selv mere magt, så han nemmere kunne ændre forfatningen og ændre lovene, der ledte til en samlet oppositions modstand mod Morsi og hans regering og kæmpedemonstrationer, hvor befolkningen krævede hans afgang.

Morsi blev herefter tvunget til at træde tilbage af militæret, der overtog præsidentembedet med hjælp fra støtter af den forrige præsident Mubarak og i en kontrarevolutionær indsats slog hårdt ned på Morsis parti Det Muslimske Broderskab samt dets støtter og dermed satte en stopper for den ellers positive udvikling i landet.

Grunden til, at netop Egypten er så vigtig for Boserup og bogens pointe, er, at det er her man i første omgang ser en tilbagegang for den revolutionære udvikling, som man ellers har set på dette her tidspunkt. Boserup argumenterer for, at Egypten og den forholdsvis succesfulde kontrarevolution blev en inspirationskilde for en lang række lande i regionen. Man har set denne strategi i større og mindre grad i næsten alle lande i Det Arabiske Forår, men især i Syrien hvor Bashar al-Assad valgte at slå brutalt ned på demonstranterne i stedet for at give indrømmelser. Man så dermed også en eskalering af magtanvendelsen, der flere steder udviklede sig fra relativt fredelige demonstrationer til kampe og visse steder borgerkrig.

\section{Indblanding udefra}

I sidste halvdel af bogen kommer Boserup ind på en af de faktorer, der i sidste ende 
gjorde, at Det Arabiske Forår blev taget ud af hænderne af dem, som startede det hele, og lagt over til politikere og statsledere, der ikke havde haft nogen indflydelse på den oprindelige græsrodsbevægelse.

Efterhånden som oprørene i de arabiske lande rystede eller helt ændrede lederskabet, blev der også rodet op i den magtbalance, der havde eksisteret i Mellemøsten de sidste mange år. Relativt nye spillere i regionen som Tyrkiet og Qatar så sit snit til at støtte oprørene, der i starten så ud til at skulle ændre styreformen i et centralt land som Egypten. På samme måde så Saudi-Arabien en mulighed for at få sat en stopper for Irans stadig større magt i Mellemøsten ved at støtte oprøret mod al-Assad og hans regering, der er kendt som en af de mest loyale af Irans allierede.

I sidste ende blev Det Arabiske Forår overtaget af stormagtspolitik og terrorfrygt fra de mest magtfulde nationer i verden, herunder især Rusland og USA. Boserup fremhæver, hvordan denne indblanding af kræfter udefra førte til, at Det Arabiske Forår udviklede sig til en stedfortræderkrig, hvor fokus blev flyttet fra den oprindelige konflikt mellem autoritære regeringer og deres befolkninger og over mod regionale magtbalancer og stormagters indflydelse og sikkerhedspolitik i regionen.

Rasmus Boserup slutter med at pointere, at selvom Det Arabiske Forår udviklede sig fra demonstrationer med krav om medbestemmelse og forandring til en krig om sikkerhed og indflydelse, er der ikke noget, der tyder på, at de problemer, som i første omgang udløste oprørene, er blevet løst.

Samtidig kan man håbe, at Det Arabiske Forår har ført til en øget bevidsthed blandt de arabiske befolkninger, når det kommer til, hvor meget magt de faktisk kan udøve, hvis de vil.

Til sidst i bogen kommer Boserup med forslag til, hvad der fra Danmarks og Europas side kan gøres for Mellemøsten. Han understreger vigtigheden af, at vi fra Vestens side forstår, at det der sker i Mellemøsten har betydning for os - om det så er via flygtningestrømme eller terrorangreb. Netop fordi det i en globaliseret verden er umuligt for Europa at blande sig udenom, hvad der sker i Mellemøsten, må løsningen i stedet være, at Danmark og Europa på både den korte og den lange bane involverer sig mere i løsninger, der på sigt kan skabe både stabilitet og sikkerhed i området.

\section{Fra forår til vinter}

Rasmus Boserups afsluttende forslag til, hvordan vi kan håndtere situationen $\mathrm{i}$ Mellemøsten, er et godt eksempel på den gennemgående følelse man får, når man læser Efter Foråret.

På den ene side er Mellemøsten tydeligvis så underlagt dets egne korrupte politikere og udefrakommende magter, at det kan virke totalt uløseligt og umuligt at få sat gang i nogen former for positiv udvikling. På den anden side er det vigtigt at huske, at der rent faktisk blev sat gang i en positiv udvikling, og at der ikke er noget underliggende ved Mellemøsten, der gør, at regionen er dømt til altid at mislykkes.

Rasmus Boserup giver i Efter Foråret et godt og fyldestgørende overblik over, hvad det var der skete, da Det Arabiske Forår startede, og det er tydeligt, at han har haft til målsætning at gøre folk klogere og samtidig punktere en masse myter. Det lykkes ham godt.

Bogen er bygget godt og intuitivt op, og ved at give hver fase i Det Arabiske Forår sit eget kapitel er den blevet overskuelig, og der er en tydelig rød tråd igennem hele værket. Bogen er med sit ikke alt for akademiske sprog, sin overskuelige op- 
bygning og sine mange eksempler god for mennesker, der ikke har meget mere end en basal viden om Mellemøsten. Samtidig kan læsere med en større viden om emnet også få en masse ud af bogen, da den kommer godt rundt om de temaer, den undersøger, og får sat en udvikling, der virker totalt kaotisk, i system, ligesom den giver nogle nye vinkler på svære problemstillinger.

I Efter Foråret får man et godt overblik over nogle af de vigtigste aspekter ved Det Arabiske Forår, formidlet på en spændende og indsigtsrig måde. Læsværdig er Boserups udlægning af, hvordan autoritære regimer kan udnytte det faktum, at et demokrati skal give plads til de store forskelle, der findes i mange arabiske befolkninger, til at splitte folkeligt støttede revolutioner
På den negative side får Boserup i nedkogningen af Det Arabiske Forår forsimplet konflikten så meget, at det ikke kommer med, at der er rigtig mange andre faktorer, der spiller ind. Dette eksemplificeres ved hans håndteringsforslag, der umiddelbart kan virke enkelt, men i virkeligheden ville være enormt komplekst og ressourcekrævende at få til at virke.

Når det er sagt, ville en bog, der skulle nå rundt om alle aspekter af Det Arabiske Forår, blive utrolig lang og indviklet. Det gode ved Efter Foråret er jo netop at den på få sider kommer godt rundt om et svært emne, og den er spændende, letlæselig og anbefalelsesværdig læsning for alle, der interesserer sig for Mellemøsten og vil vide mere om, hvad der var der skete under Det Arabiske Forår. 